\title{
Illuminating women's hidden contribution to the foundation of theoretical population genetics
}

Samantha Kristin Dung, ${ }^{1, a}$, Andrea López ${ }^{1, a}$, Ezequiel Lopez Barragan ${ }^{1, a}$, Rochelle-Jan Reyes ${ }^{1, a}$, Ricky Thu ${ }^{1, a}$, Edgar Castellanos ${ }^{\mathrm{a}}$, Francisca Catalan ${ }^{\mathrm{a}}$, Emilia Huerta Sanchez ${ }^{2, \mathrm{~b}^{*}}$, Rori V.

Rohlfs $^{2, a^{*}}$

a San Francisco State University, Department of Biology, San Francisco, CA 94132

${ }^{b}$ University of California, Merced, Division of Molecular and Cell Biology, Merced, CA 95340

* corresponding authors

${ }^{1}$ these authors contributed equally

2 these senior authors contributed equally

*Correspondence: ehuerta-sanchez@ucmerced.edu,rrohlfs@sfsu.edu 


\section{Women programmers in population genetics}

Keywords: acknowledged programmer; authorship; computational biology; population genetics; women in science

Correspondence:

Emilia Huerta Sanchez

SE1 346; Merced, CA 95343

(510) 643-0060

ehuerta-sanchez@ucmerced.edu

Rori Rohlfs

1600 Holloway Ave; San Francisco, CA 94132

(415) 405-3777

rrohlfs@sfsu.edu 


\section{Abstract}

Plentiful evidence shows an historic and continuing gender gap in participation and success in scientific research. However, less attention has been directed at clarifying obscured contributions of women to science. The lack of visible women role models (particularly in computational fields) contributes to a reduced sense of belonging and retention among women. We seek to counteract this cycle by illuminating the contribution of women programmers to the foundation of our own fields- population and evolutionary genetics. We consider past 'acknowledged programmers' (APs), who developed, ran, and sometimes analyzed the results of early computer programs. Due to authorship norms at the time, these programmers were credited in the acknowledgments sections of manuscripts, rather than being recognized as authors. For example, one acknowledgement reads "I thanks Mrs. M. Wu for help with the numerical work, and in particular for computing table I.". We identified APs in Theoretical Population Biology articles published between 1970 and 1990. While only $7 \%$ of authors were women, $43 \%$ of APs were women. This significant difference $(p=$ $\left.4.0 \times 10^{-10}\right)$ demonstrates a substantial proportion of women's contribution to foundational computational population genetics has been unrecognized. The proportion of women APs, as well as number of APs decreased over time. These observations correspond to the masculinization of computer programming, and the shifting of programming responsibilities to individuals credited as authors (likely graduate students). Finally, we note recurrent APs who contributed to several highly-cited manuscripts. We conclude 
bioRxiv preprint doi: https://doi.org/10.1101/360933; this version posted July 5, 2018. The copyright holder for this preprint (which was not certified by peer review) is the author/funder, who has granted bioRxiv a license to display the preprint in perpetuity. It is made available under aCC-BY-NC 4.0 International license.

that, while previously overlooked, historically, women have made substantial contributions to computational biology. 
In the 1970s, leaders in population genetics developed innovative theories and methods to test evolutionary hypotheses [Ewens 1972, Felsenstein 1972, Watterson 1975]. Many of these seminal methods continue to enjoy wide application with current data, some 40 years later. Innovative population geneticists developed these methods despite a lack of data. Especially in the absence of large datasets, computer simulations and numerical approaches were essential to validate these methods. Based on authorship, it seems that this foundational research was conducted by a relatively small number of independent individual scientists, nearly all of whom were men.

In some of the seminal papers from this time, we noticed that non-author computer programmers are thanked in the acknowledgments [Watterson 1975]. While these contributions may have resulted in authorship today, this practice was well within authorship norms of the time. Today, when the historical scientific contributions of women and people of color are being increasingly revealed to popular audiences (e.g., Hidden Figures) [Shetterly 2016, Evans 2018], we were curious about the scientific contribution of these "acknowledged programmers" (APs) to population genetics.

\section{Quantifying the contribution of Acknowledged Programmers}

We selected Theoretical Population Biology (TPB) as our target journal because of its high density of foundational population genetics articles that involved programming. We manually collected the author names, institutional affiliations, acknowledgements text, 
and APs for all articles published in TPB 1970 to 1990. We classified both authors and APs into binary gender categories (men and women, see Supplemental Information).

Cumulatively, over 883 articles, of individuals with classifiable binary gender, significantly more APs were women (43.2\%) as compared to authors (7.4\%) (Table 1) (two-tailed Fisher exact test, $p=4.0 \times 10^{-10}$ ). This difference is even more striking when considering the 1970 s on their own, when $7.0 \%$ of authors were women and $58.6 \%$ of APs were women (Supplemental Table 2). In this era, if we consider women APs, the contributions of women are nearly $150 \%$ higher than if we only consider authorship.

The acknowledgement of women programmers peaks in the mid 1970s, after which the ratio of women APs decreases significantly (Figure 1, Supplemental Figures 1 and 2, Supplemental Table 3, one-tailed Fisher exact test, $p=4.3 \times 10^{-3}$ ). This parallels the broader cultural shift which moved computer programming from pink collar work to a respected male-dominated field [Vogel, 2017]. Between the 1970s and 1980s, the practice of acknowledging programmers lost popularity as programming duties were likely transferred to graduate students who received authorship (Supplemental Table 4, two-tailed Fisher exact test, $p=0.034$ ) [W. Hill, personal communication, May 2018].

\section{Acknowledged Programmer narratives and contributions}

To begin to assess if papers with AP contributors had a disproportionate impact, we compared the number of citations for AP, versus non-AP papers. More high-citation 
papers (>500 citations) were produced with APs (one-tailed Fisher exact test $p=0.055$, Supplemental Figure 3, Supplemental Table 5).

In our data, three APs were acknowledged more than once over the years. When Barbara McCann worked as a research assistant at Brown University [Milbank, 1970], she was an AP for two articles in TPB (Supplemental Table 1), as well as authoring two papers (Supplemental Table 8). Jennifer Smith was acknowledged for programming and numerical analysis in three articles in TPB, as well as at least three additional articles in Biometrics when she was a computing assistant at University of Edinburgh (Supplemental Table 6). Lastly, while Margaret Wu was a research assistant in the Department of Mathematics at Monash University, she was acknowledged in two papers in TPB, one of which has been cited over 3300 times as it established a widely used estimator of genetic diversity (Supplemental Table 9). She was an AP in at least three additional manuscripts (see Supplemental Methods and Supplemental Table 7). Dr. Wu went on to earn a PhD and hold a faculty position at the University of Melbourne where she developed statistical methods to analyze educational data [Wu, 2011].

The specific technical contribution of an AP likely varied over projects. However, the fact that authors repeatedly chose to work with some APs suggests that these recurrent APs contributed particular expertise. Specifically, in addition to programming and numerical work, Jennifer Smith developed algorithms to carry out verbally specified analyses [W. 
Hill, personal communication, May 2018]. Margaret Wu performed a variety of statistical work including developing estimators for parameter values, devising algorithms for statistical tasks, and sometimes creating numerical methodology [M. Wu, personal communication, May 2018].

\section{Scientific contributions and authorship norms}

Our retrospective analysis has shed light on the contributions of women to computational genetics research, a field that was drastically skewed towards male authorship. These women's contributions were previously obscured by being relegated to footnote acknowledgements due to authorship norms. We showed that women's contribution was substantial when measured by volume (the high proportion of contributions from women APs), as well as by quality when we consider that some women APs were involved in seminal papers and development of cutting edge approaches.

This raises questions about how our current norms of scientific credit may favor certain individuals or groups. For instance, the bibliometric $h$ index ( $h$ such that a scholar authored $h$ papers that have been cited at least $h$ times) has gained popularity, in part due to its correlation with other indicators of academic success such as National Academy membership or Nobel prize laureateship [Hirsch, 2005]. However, this concordance may reflect that the $h$ index is consistent with biases in scientific recognition processes [Kelly and Jennions, 2007]. Current authorship practices also 
bear examination. In this age of highly collaborative science, authorship can be complex, including non-contributor authors (estimated in 35\% of publications in biology), as well as non-author contributors, particularly technicians (estimated in 56\% of publications in biology) [Jabbehdari and Walsh, 2017]. Because scientific role (e.g., technician, student, PI) is related to social factors (e.g., gender, race, class background, nationality), contributions from particular groups will likely remain obscured.

Revealing the scientific contribution of women is particularly important in a sub-field of biology that has been unusually male-dominated, both historically and currently [Telis, 2017]. We wonder if this represents a general trend where women's contributions in many scientific fields have been relegated to footnote acknowledgments, contributing to a false impression of a lack of participation of women in STEM fields. This historical narrative and our methodological approach, if applied in other scientific fields, can help to positively change the perception of womens' role in scientific fields and be a motivating force for continued female participation. Because perceiving under-representation in the field can impact a woman's performance [Steele, 1997, Cheryan et al., 2015], providing a counter narrative in and of itself may play a role in improving gender equity.

\section{Author Contributions}

Conceptualization, E.H.S., and R.V.R; Methodology, E.H.S., and R.V.R; Data Curation, E.C., F.C., S.K.D., A.L., E.L.B., R.-J.R., and R.T.; Investigation, S.K.D., A.L., E.L.B., 
R.-J.R., R.V.R., and R.T.; Writing, S.K.D., E.H.S., A.L., E.L.B., R.-J.R., R.V.R., and R.T.; Supervision, E.H.S., and R.V.R.

\section{Acknowledgements}

This work was funded by SF BUILD NIH grant number 1UL1GM118985 and EHS was supported by NSF grant NSF-DEB-1557151. We would like to thank Michael DeGiorgio, Tracey Heath, Emily Jane McTavish, Rasmus Nielsen, and Pleuni Pennings for constructive comments on an earlier version of this manuscript, as well as Michael Turelli, Jim Harner, and Michael Rose for helping identify the genders of ambiguously named APs. We are also grateful to Bill Hill for information that shaped our research.

\section{Declaration of Interests}

The authors declare no competing interests. 


\section{References}

Steele, CM. A threat in the air: How stereotypes shape intellectual identity and performance. American Psychologist. 1997; 52(6): 613-629.

Felsenstein J. The evolutionary advantage of recombination. Genetics. 1974; 78(2): 737-756.

Ewens WJ. The sampling theory of selectively neutral alleles. Theoretical Population Biology. 1972; 3(1): 87-112.

Watterson GA. On the number of segregating sites in genetical models without recombination. Theoretical Population Biology. 1975; 7(2):256-76.

Shetterly, M.L. (2016) Hidden Figures: The American Dream and the Untold Story of the Black Women Mathematicians Who Helped Win the Space Race. (New York City: William Morrow).

Evans, C.L. (2018) Broad Band: The Untold Story of the Women Who Made the Internet. (New York City: Penguin)

Front Matter (1970) The Milbank Memorial Fund Quarterly 48, 1-7. https://www.jstor.org/stable/pdf/3349285.pdf 
Wu,

M.

(2011)

Curriculum

vitae.

www.cdhpd.ndhu.edu.tw/ezfiles/53/1053/attach/35/pta_11174_2345834_04754.doc

Vogel, W. (2017) 'The Spitting Image of a Woman Programmer': Changing Portrayals of Women in the American Computing Industry, 1958-1985. IEEE Annals of the History of Computing 49-64.

Hirsch, J. E. (2005). An index to quantify an individual's scientific research output. PNAS 102, 16569-16572.

Kelly, C.D, and Jennions, M.D. (2007) H-index: age and sex make it unreliable. Nature 449, 403.

Jabbehdari, S. and Walsh, J.P. (2017) Authorship Norms and Project Structures in Science. Science, Technology, \& Human Values 42, 872-900.

Telis, N. (2017) Questions and answers about questions. https://telis.blog/2017/11/06/questions-and-answers-about-questions/ 
bioRxiv preprint doi: https://doi org/10.1101/360933; this version posted July 5, 2018. The copyright holder for this preprint (which was not certified by peer review) is the author/funder, who has granted bioRxiv a license to display the preprint in perpetuity. It is made available under aCC-BY-NC 4.0 International license.

Cheryan, S., Master, A., and Meltzoff, A.N. (2015) Cultural stereotypes as gatekeepers:

increasing girls' interest in computer science and engineering by diversifying stereotypes. Frontiers in Psychology 6, 49. 
Figure 1: Total number of programmers acknowledged per year in Theoretical Population Biology

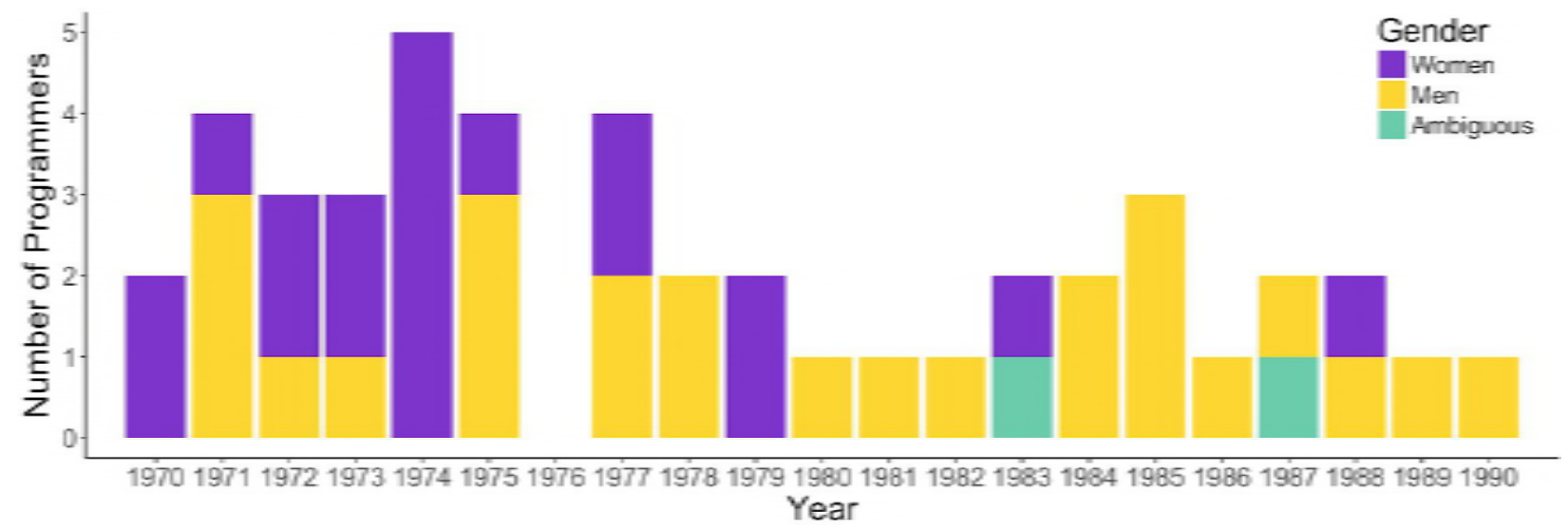

Each bar indicates the total number of acknowledged programmers broken down by binary gender. 
bioRxiv preprint doi: https://doi.org/10.1101/360933; this version posted July 5, 2018. The copyright holder for this preprint (which was not certified by peer review) is the author/funder, who has granted bioRxiv a license to display the preprint in perpetuity. It is made available under aCC-BY-NC 4.0 International license.

Table 1: Author and acknowledged programmer gender

\begin{tabular}{|l|l|l|}
\cline { 2 - 3 } \multicolumn{1}{c|}{} & Authors & APs \\
\hline Female & 80 & 19 \\
\hline Male & 998 & 25 \\
\hline Ambiguous & 164 & 2 \\
\hline
\end{tabular}




\section{Supplemental Methods}

\section{Gender classification}

Classification into binary gender categories was performed for all authors and APs (Supplemental Tables 1 and 9). While the use of these binary categories excludes transgender and gender nonconforming individuals, limiting the accuracy and scope of our analysis, collecting more detailed gender information from these data is practically infeasible. The binary gender analysis presented here is still informative of broad gender dynamics.

When a full, commonly-understood, gender-specific name, or when honorifics (ex: Miss. or Mr.) were provided, gender categorization was straight-forward. However, gender classification was less obvious when provided an individual's first initial and or a gender-neutral name. To classify an author's gender, we sought supplementary evidence. For example, by referring a publication, we learned that J. A. Sved is John A. Sved (Sved, 1971; Kidwell et al., 1977). Another example is G.L.Yang, whose full name was identified via a book published in the same field by Grace Lo Yang, who had the same university affiliation (Yang, 1972; Cam and Yang 2000). The sources of our evidence (i.e., website addresses) are documented in Supplementary Table 9.

\section{Programmer classification}

We identified programmers through key phrases in acknowledgement section such as "ably programming and executing all the computations" (Supplemental Table 1). 
However, in some cases the acknowledgements were ambiguous about specific technical role, for example, "carrying out the computing" (Supplemental Table 1). In these cases, we evaluated if the study required programming for the task indicated. The vast majority of individuals acknowledged made non-computational contributions. These non-programmers were acknowledged for contributions like "typing the manuscript," or "helpful comments and financial support".

\section{Citation analysis}

Between 7 and 12 June, 2018, we recorded the number of citations for each article in the dataset according to Google Scholar (Supplemental Figure 3). We compare the proportion of high-citation papers (those with at least 500 citations) between AP-supported and non-AP manuscripts, finding nearly significantly more high-citation papers among the AP manuscripts (one-tailed Fisher exact test $p=0.055$, Supplemental Table 5).

\section{Repeat acknowledged programmers}

We researched more articles outside our original TPB dataset where repeat APs were acknowledged. As an illustrative example, consider Jennifer Smith, who was acknowledged by William Hill in TPB. We used Google Scholar to find articles by "William G. Hill" and "W.G.Hill" between the years 1965 and 1980. After ensuring that the William Hill who authored these newly identified manuscripts had the same affiliation 
as the original William Hill (Institute of Animal Genetics in Edinburgh or lowa State University), we examined the acknowledgements section in each resulting article. The articles where Jennifer Smith is acknowledged for programming are documented in Supplemental Table 6. Analogous searches were performed for Barbara McCann and Margaret Wu (Supplemental Tables 7 and 8).

\section{Changing AP gender ratio}

To determine if the gender ratio of APs differed between the 1970s and 1980s, we performed a one-tailed Fisher exact test to determine if the proportion of women APs decreased. There were a total of 373 articles in the 1970-1979 and 364 articles in the 1980-1990. There were 17 female programmers and 12 male programmers acknowledged in the 1970s. The 1980s had two female programmers and 13 male programmers. The proportion of female programmers was significantly lower in the 1980s $(p=0.00425)$ compared to the 1970s.

\section{Supplemental citations}

Cam, L. L., Yang L. G. (2000). Asymptotics in Statistics: Some Basic Concepts. New York, NY: Springer Science + Business Media New York. 
Goodisman, Michael A. D. "ROSS H. CROZIER (1943-2009)." Entomologica Americana, vol. 116, no. 1/2, 2010, pp. 92-94. JSTOR, JSTOR, www.jstor.org/stable/40983151.

Kidwell, M. G., Kidwell, J. F., \& Sved, J. A. (1977). Hybrid Dysgenesis in Drosophila Melanogaster: A Syndrome of Aberrant Traits Including Mutation, Sterility and Male Recombination. Manuscript, GENETICS, Division of Biology and Medicine, Brown University, Providence, Rhode Island 02912, School of Biological Sciences, University of Sydney, N. S. W. 2006, Australia . Retrieved from http://www.genetics.org/content/86/4/813.short

Sved, J. A. (1971). Heterosis at the level of the chromosome and at the level of the gene. Manuscript, Theoretical Population Biology, School of Biological Sciences, University of Sydney, New South Wales, Australia.

Yang, G. (1972). On the probability distributions of some stochastic epidemic models. Theoretical Population Biology, 3(4), 448-459. doi:10.1016/0040-5809(72)90016-0 
Supplemental Table 1: Acknowledged programmers

\begin{tabular}{|c|c|c|c|}
\hline Year & Name & Gender & Acknowledgement \\
\hline 1970 & $\begin{array}{l}\text { Mrs. H. Walker } \\
\text { Barbara McCann }\end{array}$ & $\begin{array}{l}\text { Female } \\
\text { Female }\end{array}$ & $\begin{array}{l}\text { “...Mrs. H. Walker for computing Tables II, III, and } \\
\text { IV..." } \\
\text { “...programming assistance of Barbara } \\
\text { McCann,..." }\end{array}$ \\
\hline 1971 & $\begin{array}{l}\text { Mr. J. Robinson } \\
\text { Miss E.P. Bennett } \\
\text { Professor B.D.H. } \\
\text { Latter } \\
\text { Dr. E[ric] N. West }\end{array}$ & $\begin{array}{l}\text { Male } \\
\text { Female } \\
\text { Male } \\
\text { Male }\end{array}$ & $\begin{array}{l}\text { “...Mr. J. Robinson and Miss E.P. Bennett for } \\
\text { assistance with computer programming.” } \\
\text { “...Professor B.D.H. Latter and Dr. E.N. West for } \\
\text { help in computing tables I, II, IV, and V,..." }\end{array}$ \\
\hline 1972 & $\begin{array}{l}\text { Barbara McCann } \\
\text { Joan Kieper } \\
\text { Mr. M. Legg }\end{array}$ & $\begin{array}{l}\text { Female } \\
\text { Female } \\
\text { Male }\end{array}$ & $\begin{array}{l}\text { "...programming assistance of Barbara McCann } \\
\text { and Joan Kieper..." } \\
\text { "Mr. M. Legg for carrying out the computer } \\
\text { programming to solve equations." }\end{array}$ \\
\hline 1973 & $\begin{array}{l}\text { Mrs. M. Driver } \\
\text { Paul Roda } \\
\text { Lucy B.B. Rowe }\end{array}$ & $\begin{array}{l}\text { Female } \\
\text { Male } \\
\text { Female }\end{array}$ & $\begin{array}{l}\text { "...Mrs. M. Driver who carried out the computations } \\
\text { required for the figures." } \\
\text { "...Paul Roda for programming the solution to the } \\
\text { likelihood equations..." } \\
\text { "...Lucy B. B.Rowe for computer work." }\end{array}$ \\
\hline 1974 & $\begin{array}{l}\text { Mrs. Jennifer Smith } \\
\text { Dianne Hollenbeck } \\
\text { Mrs. J[ennifer]. Smith } \\
\text { Miss M. Chang } \\
\text { Miss L. Moore }\end{array}$ & $\begin{array}{l}\text { Female } \\
\text { Female } \\
\text { Female } \\
\text { Female } \\
\text { Female }\end{array}$ & $\begin{array}{l}\text { “...Mrs. Jennifer Smith for ably programming and } \\
\text { executing all the computations." } \\
\text { "...excellent computing assistance of Dianne } \\
\text { Hollenbeck." } \\
\text { "...Mrs. J Smith for carrying out the computing." } \\
\text { "...Miss M. Chang and Miss. L. Moore for } \\
\text { computing the tables.” }\end{array}$ \\
\hline 1975 & $\begin{array}{l}\text { Mr. Kukuhisa } \\
\text { Jeffrey H. Kinrich } \\
\text { Mrs. M[argaret] Wu } \\
\text { Boris Skolar }\end{array}$ & $\begin{array}{l}\text { Male } \\
\text { Male } \\
\text { Female } \\
\text { Male }\end{array}$ & $\begin{array}{l}\text { "...Mr. Kukuhisa for his assistance in running the } \\
\text { computer programs." } \\
\text { "...Jeffrey H. Kinrich... programmed most of the } \\
\text { calculations reported in this paper." } \\
\text { "...Mrs. M. Wu for help with the numerical work, } \\
\text { and in particular for computing Table 1." } \\
\text { "...Boris Skolar for carrying out the computer }\end{array}$ \\
\hline
\end{tabular}




\begin{tabular}{|c|c|c|c|}
\hline & & & work." \\
\hline 1976 & NA & NA & NA \\
\hline 1977 & $\begin{array}{l}\text { Marjorie McEwan } \\
\text { Jenny [Jennifer] Smith } \\
\text { Yoshio Tateno } \\
\text { T[om] Carney }\end{array}$ & $\begin{array}{l}\text { Female } \\
\text { Female } \\
\text { Male } \\
\text { Male }\end{array}$ & $\begin{array}{l}\text { “...Marjorie McEwan and Jenny Smith for } \\
\text { Computing assistance." } \\
\text { “...Yoshio Tateno for his valuable help in computer } \\
\text { programming." } \\
\text { “...T. Carney for programming assistance..." }\end{array}$ \\
\hline 1978 & $\begin{array}{l}\text { Christopher } \\
\text { Hermansen } \\
\text { Randy Sharp }\end{array}$ & $\begin{array}{l}\text { Male } \\
\text { Male }\end{array}$ & $\begin{array}{l}\text { "...Christopher Hermansen for his computational } \\
\text { assistance." } \\
\text { "Randy Sharp's able programming assistance..." }\end{array}$ \\
\hline 1979 & $\begin{array}{l}\text { Mrs. M. Ortner } \\
\text { M[rs]. M[argaret] Wu }\end{array}$ & $\begin{array}{l}\text { Female } \\
\text { Female }\end{array}$ & $\begin{array}{l}\text { "Mrs. M. Ortner for considerable computational and } \\
\text { editorial help" } \\
\text { "...M. Wu for helping with the computing." }\end{array}$ \\
\hline 1980 & Frank Archibeque & Male & "Frank Archibeque helped in the computing..." \\
\hline 1981 & Hugh Everett & Male & "Hugh Everett for his efficient programming..." \\
\hline 1982 & Rod Thompson & Male & $\begin{array}{l}\text { "The simulations were expertly programmed by } \\
\text { Rod Thompson." }\end{array}$ \\
\hline 1983 & $\begin{array}{l}\text { S. Kennedy } \\
\text { Mrs. Barbara } \\
\text { Anderson }\end{array}$ & $\begin{array}{l}\text { Unknown } \\
\text { Female }\end{array}$ & $\begin{array}{l}\text { "...S. Kennedy for assistance in programming." } \\
\text { "...Mrs. Barbara Anderson for computer assistance } \\
\text { in numerical studies of the model." }\end{array}$ \\
\hline 1984 & $\begin{array}{l}\text { R. Barker } \\
\text { R. Kennedy }\end{array}$ & $\begin{array}{l}\text { Male } \\
\text { Male }\end{array}$ & $\begin{array}{l}\text { "...R. Barker and R. Kennedy for computer } \\
\text { programming...” }\end{array}$ \\
\hline 1985 & $\begin{array}{l}\text { Pankaj Shah } \\
\text { P.E. Johnston } \\
\text { P.E. Johnston }\end{array}$ & $\begin{array}{l}\text { Male } \\
\text { Male } \\
\text { Male }\end{array}$ & $\begin{array}{l}\text { "...Pankaj Shah for doing much of the } \\
\text { programming...” } \\
\text { "...P.E. Johnston for help with programming..." } \\
\text { "...P.E. Johnston for help with programming." }\end{array}$ \\
\hline 1986 & John Spalding & Male & $\begin{array}{l}\text { "John Spalding... helped greatly with the computer } \\
\text { simulations and graphics." }\end{array}$ \\
\hline 1987 & Mr. P. Mancini & Male & $\begin{array}{l}\text { "...Mr. P. Mancini for his excellent technical } \\
\text { assistance in computer simulations." }\end{array}$ \\
\hline
\end{tabular}




\begin{tabular}{|l|l|l|l|}
\hline & T. Roeder & Unknown & “...T. Roeder for computing work..." \\
\hline 1988 & $\begin{array}{l}\text { Shiang-tai Tuan } \\
\text { Susan Paulsen }\end{array}$ & $\begin{array}{l}\text { Male } \\
\text { Female }\end{array}$ & $\begin{array}{l}\text { “...Shiang-tai Tuan and Susan Paulsen for } \\
\text { programming." }\end{array}$ \\
\hline 1989 & James Bradley & Male & $\begin{array}{l}\text { "...James Bradley for assistance with plotting some } \\
\text { of the simulation results...” }\end{array}$ \\
\hline 1990 & Mr. G. Baglioni & Male & $\begin{array}{l}\text { "...Mr. G. Baglioni for computer technical } \\
\text { assistance..." }\end{array}$ \\
\hline
\end{tabular}

Each acknowledged programmer is indicated by year. The binary gender of each programmer is identified, when possible. Underlined and italicized names are APs who were acknowledged more than once in different years. 
bioRxiv preprint doi: https://doi org/10.1101/360933; this version posted July 5, 2018. The copyright holder for this preprint (which was not certified by peer review) is the author/funder, who has granted bioRxiv a license to display the preprint in perpetuity. It is made available under aCC-BY-NC 4.0 International license.

Supplemental Table 2: Author and acknowledged programmer gender from 1970 through 1979

\begin{tabular}{|l|l|l|}
\cline { 2 - 3 } \multicolumn{1}{l|}{} & Authors & APs \\
\hline Female & 38 & 17 \\
\hline Male & 502 & 12 \\
\hline Ambiguous & 24 & 2 \\
\hline
\end{tabular}


bioRxiv preprint doi: https://doi org/10.1101/360933; this version posted July 5, 2018. The copyright holder for this preprint (which was not certified by peer review) is the author/funder, who has granted bioRxiv a license to display the preprint in perpetuity. It is made available under aCC-BY-NC 4.0 International license.

\section{Supplemental Table 3: AP gender ratio over time}

\begin{tabular}{|l|l|l|l|}
\cline { 3 - 4 } \multicolumn{2}{c|}{} & \multicolumn{2}{l|}{ Years } \\
\cline { 3 - 4 } \multicolumn{2}{c|}{} & $1970-79$ & $1980-1990$ \\
\hline \multirow{3}{*}{ Programmer } & Female & 17 & 2 \\
\cline { 3 - 4 } & Male & 12 & 13 \\
\hline
\end{tabular}


bioRxiv preprint doi: https://doi.org/10.1101/360933; this version posted July 5, 2018. The copyright holder for this preprint (which was not certified by peer review) is the author/funder, who has granted bioRxiv a license to display the preprint in perpetuity. It is made available under aCC-BY-NC 4.0 International license.

Supplemental Table 4: Prevalence of APs over time

\begin{tabular}{|l|l|l|}
\cline { 2 - 3 } \multicolumn{1}{c|}{} & \multicolumn{2}{|l|}{ Years } \\
\cline { 2 - 3 } \multicolumn{1}{c|}{} & $1970-1979$ & $1980-1990$ \\
\hline APs & 29 & 17 \\
\hline Articles & 389 & 444 \\
\hline
\end{tabular}


bioRxiv preprint doi: https://doi org/10.1101/360933; this version posted July 5, 2018. The copyright holder for this preprint (which was not certified by peer review) is the author/funder, who has granted bioRxiv a license to display the preprint in perpetuity. It is made available under aCC-BY-NC 4.0 International license.

Supplemental Table 5: Citations of AP-supported versus non-AP papers

\begin{tabular}{|l|l|l|}
\cline { 2 - 3 } \multicolumn{1}{c|}{} & $\begin{array}{l}\text { AP-supported } \\
\text { papers }\end{array}$ & non-AP papers \\
\hline $\begin{array}{l}<500 \\
\text { citations }\end{array}$ & 36 & 778 \\
\hline $\begin{array}{l}>500 \\
\text { citations }\end{array}$ & 3 & 16 \\
\hline
\end{tabular}


Supplemental Table 6: Acknowledgements for Jennifer Smith

\begin{tabular}{|l|l|l|l|}
\hline Year & Journal & Article Title & $\begin{array}{l}\text { Indicative acknowledgments } \\
\text { text }\end{array}$ \\
\hline 1975 & Biometrics & $\begin{array}{l}\text { Tests for Association of Gene } \\
\text { Frequencies at Several Loci in } \\
\text { Random Mating Diploid Populations }\end{array}$ & $\begin{array}{l}\text { "I am indebted to ... Mrs. Jennifer } \\
\text { Smith for programming the } \\
\text { analysis on the computer." }\end{array}$ \\
\hline 1976 & Biometrics & $\begin{array}{l}\text { Order Statistics of Correlated Variables } \\
\text { and Implications in Genetic Selection } \\
\text { Programmes }\end{array}$ & $\begin{array}{l}\text { " I am indebted to Jenny Smith for } \\
\text { undertaking the numerical } \\
\text { analysis..." }\end{array}$ \\
\hline 1977 & Biometrics & $\begin{array}{l}\text { Order Statistics of Correlated Variables } \\
\text { and Implications in Genetic Selection } \\
\text { Programmes. II. Response to Selection }\end{array}$ & $\begin{array}{l}\text { " I am indebted to Jenny Smith for } \\
\text { undertaking the numerical } \\
\text { analysis." }\end{array}$ \\
\hline
\end{tabular}

This table lists the articles outside of the original Theoretical Population Biology dataset where Jennifer Smith was acknowledged for programming. The year, journal, and indicative acknowledgements text are shown. 
Supplemental Table 7: Acknowledgments for Margaret Wu

\begin{tabular}{|c|c|c|c|}
\hline Year & Journal & Article Title & Indicative acknowledgments text \\
\hline 1976 & Genetics & Heterosis or Neutrality & “... Mrs. M. Wu helped with some computing." \\
\hline 1978 & Genetics & $\begin{array}{l}\text { An Analysis of Multi-allelic } \\
\text { Data }\end{array}$ & "... Mrs. M. Wu for help with the computing." \\
\hline 1977 & Genetics & $\begin{array}{l}\text { The Homozygosity Test of } \\
\text { Neutrality }\end{array}$ & $\begin{array}{l}\text { "I thank Mrs. M. Wu for help with } \\
\text { computing..." }\end{array}$ \\
\hline
\end{tabular}

This table lists the articles outside of the original Theoretical Population Biology dataset where Margaret $\mathrm{Wu}$ was acknowledged for programming. The year, journal, and indicative acknowledgments text are shown above. Note that Margaret Wu's later career trajectory was ascertained from her

C.V. (www.cdhpd.ndhu.edu.tw/ezfiles/53/1053/attach/35/pta_11174_2345834 04754.doc). 
Supplemental Table 8: Authorship for Barbara McCann

\begin{tabular}{|l|l|l|}
\hline Year & Journal & Article Title \\
\hline 1970 & The Milbank Memorial Fund Quarterly & $\begin{array}{l}\text { Selective Fecundability and Contraceptive } \\
\text { Effectiveness }\end{array}$ \\
\hline 1970 & Population Studies & $\begin{array}{l}\text { Net Delay of Next Conception by Contraception: } \\
\text { A Highly Simplified Case }\end{array}$ \\
\hline
\end{tabular}

This table lists the articles outside of the original Theoretical Population Biology dataset where Barbara McCann is a published author. The year, journal are shown above. Note that her status as a Research Assistant at Brown University was established in the Front Material of The Milbank Memorial Fund Quarterly issue. 
Supplemental Figure 1: Acknowledged programmers per total number of articles

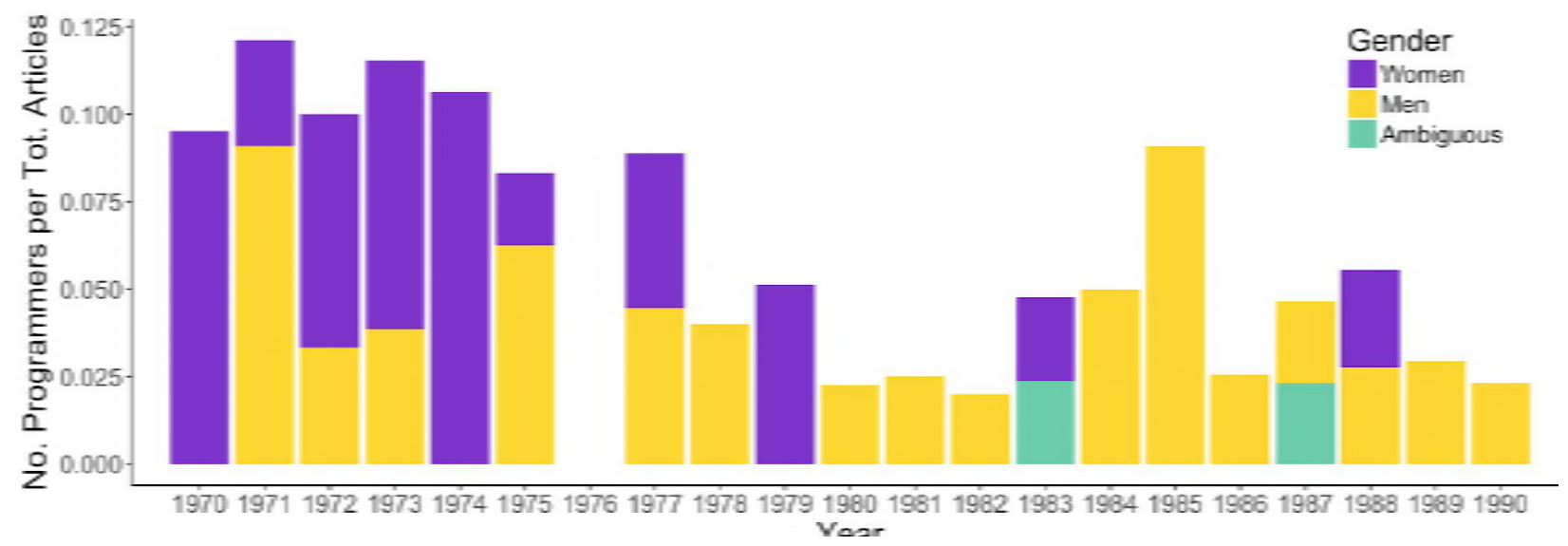

Each bar represents the frequency of acknowledged programmers per total number of articles in

a year broken down by binary gender: red indicates women, green indicates men, and blue indicates gender ambiguous programmers. 
Supplemental Figure 2: Total number of articles per year in Theoretical Population Biology

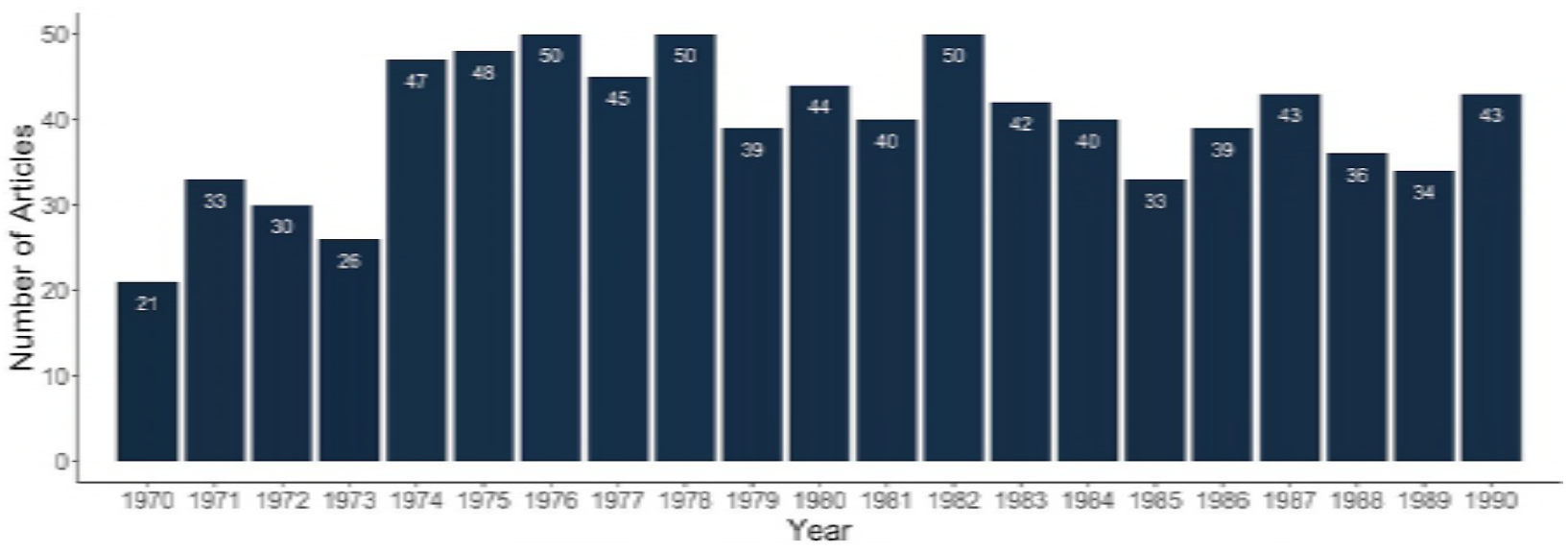

Each bar illustrates the total number of articles published in Theoretical Population Biology in one year from 1970 to 1990 . 
Supplemental Figure 3: Histogram of number of citations for AP-supported and non-AP papers

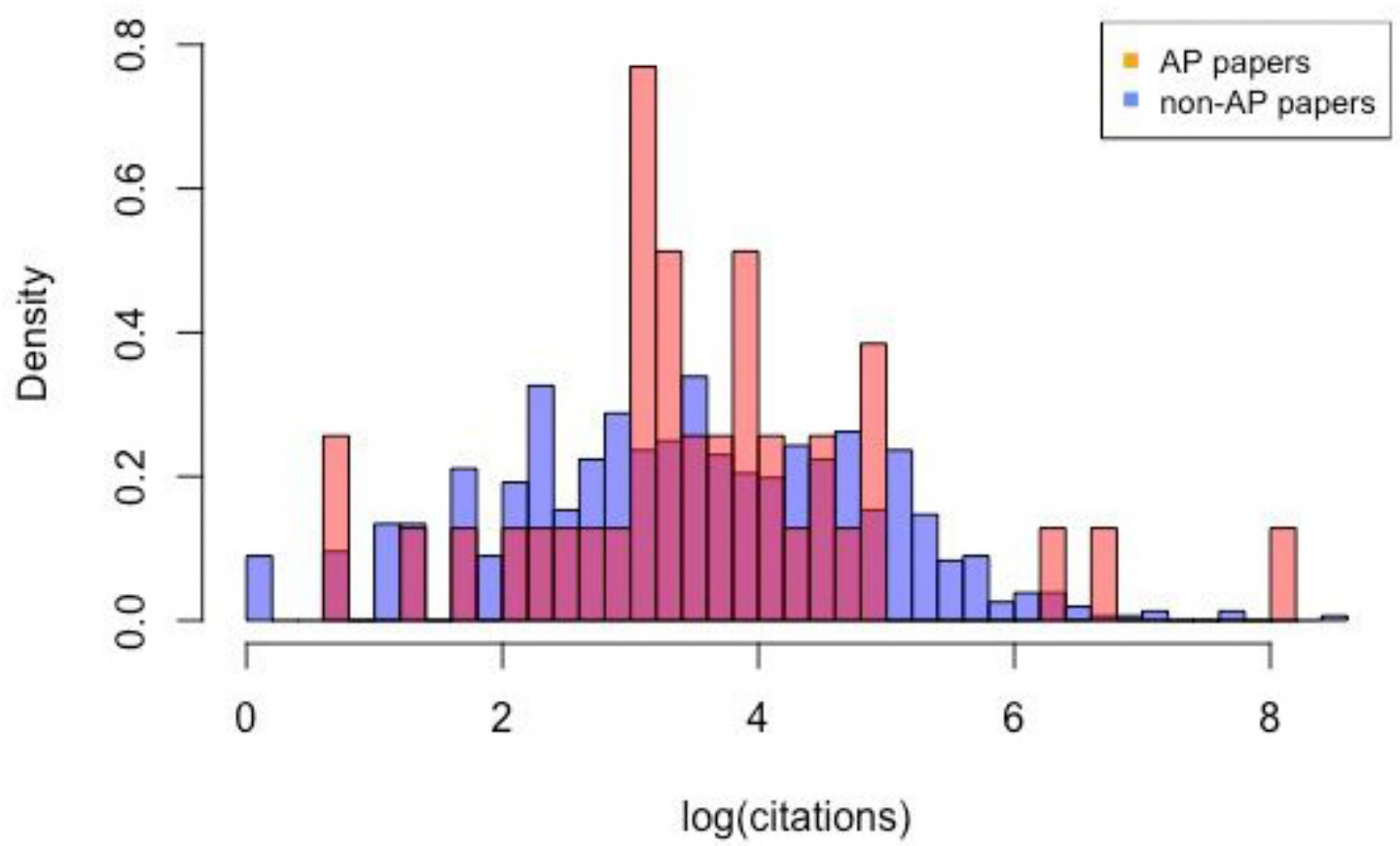

The log(number of citations) is shown for AP-supported papers (in orange) and non-AP papers (in blue). 